\title{
ANALISIS ASURANSI PERTANIAN DI INDONESIA: KONSEP, TANTANGAN DAN PROSPEK
}

\section{ANALYSIS OF AGRICULTURAL INSURANCE IN INDONESIA: CONCEPTS, CHALLENGES AND PROSPECTS}

\author{
Praptono Djunedi \\ Pusat Kebijakan Anggaran Pendapatan dan Belanja Negara, \\ Badan Kebijakan Fiskal, Kementerian Keuangan \\ JIn DR.Wahidin No.1, Jakarta, Indonesia \\ Email: praptono_dj@yahoo.com
}

Naskah diterima: 5 Maret 2015, revisi pertama: 18 Januari 2016, revisi kedua: 14 Maret 2016, revisi terakhir: 24 Maret 2016.

\begin{abstract}
Agriculture is one of the important sectorfor Indonesia. However, the sector is vulnerable to various risks that may impact on the fluctuation of the income of farmers. Related to this, through Law No. 19 of 2013, the government seeks to protect farmers, one of which is through agricultural insurance. As a start-up country, the problem faced is how to develop agricultural insurance in Indonesia. Related to that, this study aims to (1) describe the concept of agricultural insurance, (2) describe the challenges faced to develop agricultural insurance, and (3) explain how the prospect. Some of the challenges can be grouped into four challenges, namely institutional, financial, technical and operationalchallenges. For the good prospect in the future, implementation of agricultural insurance is proposed to (1) gradually increase the allocation in state budget, (2) develop technical rules which include agricultural insurance scheme in compulsory basis, (3) encourage the relevant parties to commit in developing agricultural insurance (4) assign to the state-owned insurance as providers and distributors of agricultural insurance as well as a role as reinsurance agency, (5) assess the integration between the agricultural insurance scheme and agricultural services received by farmers (subsidized fertilizer, subsidized seed, and social assistance).
\end{abstract}

Keywords: farmer, risk, agricultural insurance, premium subsidy

\begin{abstract}
Abstrak
Sektor pertanian merupakan salah satu sektor yang penting bagi Indonesia. Namun, sektor ini rentan terhadap berbagai risiko yang dapat berdampak pada berfluktuasinya pendapatan para petani. Terkait dengan hal ini, melalui Undang Undang Nomor 19Tahun 2013, pemerintah berupaya melindungi petani, salah satunya adalah melalui asuransi
\end{abstract}


pertanian. Sebagai negara start-up, permasalahan yang dihadapi adalah bagaimana cara mengembangkan asuransi pertanian di Indonesia. Terkait hal itu, tujuan kajian ini adalah (1) memaparkan konsep asuransi pertanian, (2) memaparkan berbagai tantangan yang dihadapi untuk mengembangkan asuransi pertanian, dan (3) menjelaskan bagaimana prospeknya. Beberapa tantangan yang dihadapi bisa dikelompokkan menjadi empat tantangan yakni tantangan institusional, finansial, teknis dan operasional. Agar implementasi asuransi pertanian memiliki prospek yang baik, diusulkan agar (1) meningkatkan alokasi dana implementasi asuransi pertanian dalam APBN secara bertahap, (2) menyusun aturan teknis yang diantaranya mengatur kepesertaan asuransi pertanian bersifat wajib, (3) mendorong pihak terkait sesuai dengan perannya berkomitmen mengembangkan asuransi pertanian, (4) memberi penugasan kepada BUMN asuransi sebagai penyedia dan penyalur asuransi pertanian serta berperan sebagai lembaga reasuransi, (5) mengkaji pengintegrasian antara program asuransi pertanian dengan layanan sektor pertanian yang diterima petani (pupuk bersubsidi, benih bersubsidi, dan bantuan sosial).

Kata kunci: petani, risiko, asuransi pertanian, subsidi premi.

\section{A. PENDAHULUAN}

Berdasarkan data Badan Pusat Statistik (2014), pertumbuhan Produk Domestik Bruto (PDB) Indonesia tahun 2012 dan tahun 2013 masing-masing sebesar 6,26 persen dan 5,78 persen. Dari sisi kontribusi terhadap PDB dan jumlah tenaga kerja, sektor pertanian masih merupakan salah satu sektor penting dalam perekonomian Indonesia. Dalam periode tahun 2009-2013, sektor ini menyumbang pada kisaran 14\%-15\% terhadap PDB. Pada tahun 2014, angka sumbangan sektor pertanian pada triwulan II dan III masih relatif stabil, masing-masing 14,84\% dan 15,21\%. Walaupun ada penurunan jumlah tenaga kerja sebanyak 250 ribu orang (dari 39,22 juta per Agustus 2013 menjadi 38,97 juta per Agustus 2014), sektor pertanian masih menjadi salah satu penyumbang terbesar penyerapan tenaga kerja di Indonesia.

Keberlanjutan kontribusi sektor pertanian ini bagaimanapun juga perlu mendapatkan perhatian dari berbagai pihak, mengingat banyak hal yang dapat menjadi faktor kegagalan panen.Menurut Jaffee et.al (2008) dalam FAO (2011:16), ada delapan jenis risiko yang melekat pada rantai pasok sektor pertanian yaitu risiko cuaca, bencana alam, risiko lingkungan, risiko pasar, risiko logistik, risiko operasional, risiko kebijakan dan risiko politik. Masih terkait risiko, Lee et al. (1980, dalam Sumaryanto dan Nurmanaf, 2007; Pasaribu et al, 2010) menyebutkan terdapat enam penyebab ketidakpastian yang berpengaruh pada sektor pertanian yaitu 1) berhubungan dengan faktor alam (kekeringan, serbuan hama dan penyakit), 2) bencana (banjir, kebakaran, longsor, dan letusan gunung berapi), 3) fluktuasi harga (input dan output), 4) teknologi yang menyebabkan rendahnya produktivitas dan produksi, 5) aksi pihak lain (sabotase, perampasan, dan perubahan peraturan), serta 6) kondisi petani/keluarga (meninggal, sakit parah). Menurut Hadiet al (2000) dalam Boer (2012), kejadian bencana kekeringan dan banjir sebagai penyebab utama kegagalan panen di Indonesia. Menurut Ditjen Perlindungan Tanaman Pangan Kementerian Pertanian (2008)dalam Pasaribu et al. (2010), luas areal padi yang terkena banjir, kekeringan dan hama serta penyakit masing-masing 333,2 ribu ha, 319,5 ribu ha dan 428,6 ribu ha dan berdampak pada kehilangan hasil masing-masing sebesar 997,3 ribu ton, 984,2 ribu ton dan 352,3 ribu ton. Total kehilangan produksi sekitar 2,3 juta ton (4,08 persen dari produksi total 57,17 juta ton). 
Berbagai risiko yang dihadapi sektor pertanian tersebut dapat berdampak pada stabilitas pendapatan petani. Oleh karena itu, salah satu tantangan penting sektor pertanian yaitu bagaimana meningkatkan pendapatan petani yang sebagian besar memiliki lahan kurang dari 0,5 ha per kapita. Dalam konteks ini, negara melalui pemerintah diharapkan hadir untuk memberikan perlindungan dan pemberdayaan kepada petani yang berperan dalam pembangunan sektor pertanian guna mewujudkan kedaulatan pangan, kemandirian pangan dan ketahanan pangan secara berkelanjutan. Salah satu bentuk perlindungan terhadap pendapatan atau kesejahteraan petani itu adalah asuransi pertanian.

Asuransi pertanian sudah diterapkan di banyak negara. Setidaknya ada 86 negara yang telah mengimplementasikan program asuransi pertaniannya dengan relatif baik (Mahul dan Stutley, 2010 dalam FAO, 2011:23). Salah satunya adalah negara Jepang yang mengimplementasikan program asuransi pertanian sejak tahun 1930-an. Hal ini ditandai dengan dukungan pemerintah Jepang yang menerbitkan beberapa regulasi seperti Undang-Undang Asuransi Ternak, Undang-Undang Asuransi Kehutanan Nasional dan Undang-Undang Asuransi Pertanian. Sedangkan di Indonesia, regulasi yang terkait baru diterbitkan pada tahun 2013.

Undang-Undang Nomor 19 Tahun 2013 tentang Perlindungan dan Pemberdayaan Petani mencantumkan suatu terminologi yang masih baru bagi masyarakat Indonesia yaitu "asuransi pertanian”. Dalam regulasi tersebut, asuransi pertanian merupakan salah satu alat bagi pemerintah untuk melindungi petani dari gagal panen. Gagal panen bisa terjadi akibat bencana alam, wabah penyakit hewan menular, perubahan iklim, dan risiko lainnya. Pasal 39 ayat (1) dan (2) UU 19/2013 menyatakan bahwa sesuai dengan kewenangannya, pemerintah pusat dan pemerintah daerah memfasilitasi setiap petani menjadi peseta asuransi. Salah satu fasilitasi tersebut adalah bantuan pembayaran premi. Bantuan premi tersebut berasal dari APBN dan/atau APBD, yang dibayarkan sampai dinyatakan oleh pemerintah dan pemerintah daerah bahwa petani mampu membayar preminya sendiri.

Dari paparan di atas, dapat diketahui beberapa hal yang melatarbelakangi perlunya kajian tentang asuransi pertanian ini dilakukan. Beberapa persoalan yang perlu dikaji lebih lanjut yaitu (1) bagaimana perkembangan pelaksanaan program asuransi pertanian di Indonesia? (2) apa saja tantangan yang dihadapi pemerintah dalam mengembangkan program asuransi pertanian di Indonesia? dan (3) bagaimana prospek program asuransi pertanian di masa mendatang?Itulah beberapa pertanyaan yang akan menjadi bahasan kajian ini. Adapun sistematika penulisan kajian ini diawali dengan (1) pendahuluan, kemudian dilanjutkan dengan (2) tinjauan pustaka, (3) metode penelitian, (4) hasil dan pembahasan, dan diakhiri dengan (5) penutup.

\section{B. TINJAUAN PUSTAKA}

\section{Konsep Asuransi Pertanian}

Asuransi pertanian adalah perjanjian antara petani dan pihak perusahaan asuransi untuk mengikatkan diri dalam pertanggungan risiko usaha tani (khususnya tanaman pangan, hortikultura, perkebunan dan/atau peternakan). Asuransi pertanian merupakan salah satu strategi perlindungan petani yang ditetapkan pemerintah dan pemerintah daerah sesuai dengan kewenangannya. Perlindungan petani tersebut diberikan kepada (a) petani penggarap tanaman pangan yang tidak memiliki lahan usaha tani dan menggarap paling luas dua hektar, (b) petani yang memiliki lahan dan melakukan usaha budi daya tanaman pangan pada lahan paling luas dua hektar, dan/atau (c) petani hortikultura, pekebun atau peternak skala usaha kecil (Undang-Undang Nomor 19 Tahun 2013). Menurut FAO (2011:37),jenis produk asuransi pertanian meliputi asuransi tanaman (crop insurance), 
asuransi ternak (livestock insurance), asuransi kehutanan/perkebunan (forestry/plantation), asuransi rumah kaca (greenhouse insurance), asuransi daging unggas (poultry insurance) dan asuransi budi daya perikanan (aquaculture insurance).

Secara umum, tujuan asuransi pertanian adalah untuk (1) menstabilkan pendapatan petani melalui pengurangan tingkat kerugian akibat kehilangan hasil, (2) mendorong petani mengadopsi teknologi usahatani agar lebih produktif dan efisien, dan (3) mengurangi risiko yang dihadapi lembaga perkreditan serta meningkatkan akses petani ke lembaga tersebut (Nurmanaf et al, 2007:5; Sumaryanto dan Nurmanaf, 2007:94; PASEKP, 2009:17; Supartoyo dan Kasmiati, t.t.:2). Bagi petani, manfaat dari program ini adalah (1) menyadarkan petani terhadap risiko gagal panen, (2) mendorong petani meningkatkan ketrampilan dan memperbaiki manajemen usaha pertanian, (3) mengurangi ketergantungan pada permodalan dari pihak lain dan membantu petani menyediakan biaya produksi usahatani, dan (4) meningkatkan pendapatan petani dari keberhasilan usahatani yang berkelanjutan. Bagi pemerintah daerah, program ini terutama bertujuan untuk (1) meningkatkan kesadaran dan tanggung jawab pemerintah daerah agar mengantisipasi risiko usaha pertanian yang mungkin terjadi di daerahnya, dan (2) meningkatkan keberhasilan usaha pertanian serta ketahanan pangan secara regional.

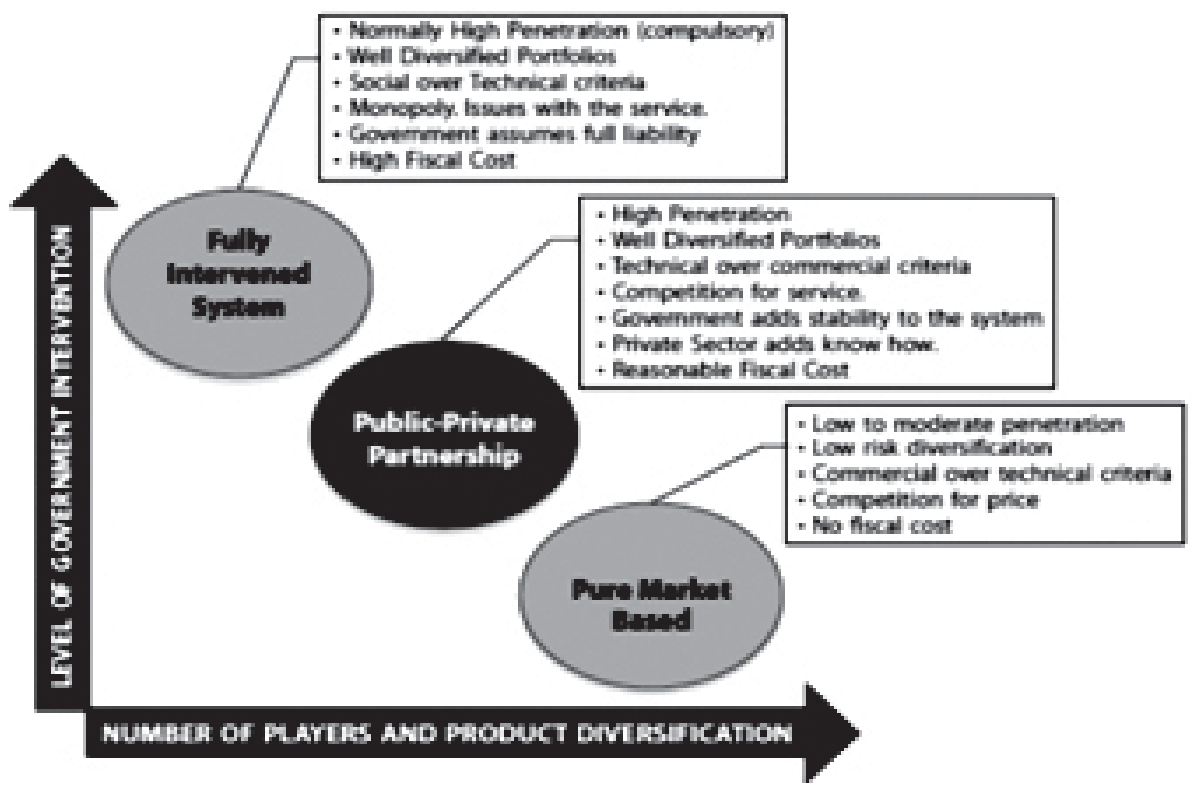

Gambar 1. Model Pengembangan Asuransi Pertanian

Sumber: Iturrioz (2009:20)dan FAO (2011:26).

Terdapat tiga model untuk mengembangkan asuransi pertanian (lihat Gambar 1) yaitu (a) fully intervened system, (b) public private partnership, dan (c) pure market based. Untuk model pertama (fully intervened system), ditandai dengan dukungan pemerintah yang sangat tinggi (high fiscal cost), penyediaan asuransi pertanian yang monopolistik dan tingkat penetrasi pasar yang tinggi. Model kedua ditandai dengan kerjasama antara perusahaan asuransi milik negara dengan perusahaan asuransi komersial, atau pasar yang terbuka dengan beberapa perusahaan komersial dengan pemerintah yang memiliki tingkat kendali tertentu berdasarkan partisipasi premi dan desain kebijakan, atau pasar terbuka dengan beberapa perusahaan komersial tetapi dengan tingkat kendali yang lebih rendah, peran pemerintah lebih kepada pemberian subsidi premi. Model yang ketiga, asuransi pertanian diterapkan tanpa partisipasi pemerintah (Iturrioz, 2009:19-20; FAO, 2011:2630). 
Beberapa alasan keterlibatan sektor publik dalam pasar asuransi pertanian adalah (1) belum adanyainfrastruktur asuransi di daerah pedesaan dan juga jasa asuransi pertanian sektor swasta, (2) tingginya biaya fase awal pengembangan produk asuransi pertanian, (3) adanya kendala kapasitas pihak reasuransi untuk menanggung risiko sistemik dalam produksi pertanian, (4) tingginya biaya administrasi asuransi pertanian, dan (5) munculnya masalah kemampuan bayar disebabkan tingginya biaya premi asuransi pertanian (World Bank, 2010:47).

\section{Tantangan Pengembangan Asuransi Pertanian}

Pengembangan program asuransi pertanian menghadapi berbagai tantangan. Menurut World Bank (2010:77), ada empat kelompok tantangan yang terkait dengan asuransi pertanian yaitu tantangan institusional, tantangan keuangan, tantangan teknis dan tantangan operasional.

Tantangan institusional berkaitan dengan kerangka kelembagaan, kerangka hukum dan peraturan, peran perusahaan asuransi dalam rangka kemitraan pembiayaan pengembangan asuransi pertanian, atau perlu tidaknya asuransi pertanian diintegrasikan dengan produk dan layanan lainnya yang diterima oleh petani. Mahul dan Stutley (2010) dalam FAO (2011:21-22)juga mempertanyakan efektivitas asuransi pertanian apabila diterapkan secara terpisah dengan layanan pertanian lainnya seperti pelatihan dan penyuluhan, penyediaan faktor produksi tepat waktu (benih, pupuk dan pestisida) serta saluran pemasaran produk-produk pertanian yang efisien.

Tantangan keuangan berkaitan dengan efisiensi biaya risiko produksi pertanian yang disusun secara berlapis, peran perusahaan asuransi domestik dalam mengelola risiko pertanian, dukungan pemerintah untuk bertindak sebagai reasuransi atau lender of last resort, perlu tidaknya peran subsidi premi asuransi pertanian didefinisikan ulang. Tingginya biaya untuk mensubsidi program asuransi pertanian juga sudah diingatkan oleh Siamwalla dan Valdes (1986) dalam Hazell et al (1986:117).

Tantangan teknis berkaitan dengan penilaian risiko produksi pertanian, penyediaan infrastruktur dan jasa informasi cuaca, R\&D untuk produk asuransi pertanian, ketepatsasaran atas produk asuransi pertanian. Terakhir, tantangan operasional berkaitan dengan peningkatan kapasitas yang diperlukan untuk merancang dan menyelenggarakan program asuransi pertanian, pengembangan pasar asuransi pertanian yang fokus pada standar produk yang sederhana untuk dikelola, mempromosikan koperasi, asosiasi produsen, BPR, dan lembaga keuangan mikro sebagai delivery channel asuransi pertanian, mempromosikan penggunaan unit dukungan teknis manajemen risiko pertanian.

\section{Prospek Pengembangan Asuransi Pertanian}

Implementasi program asuransi pertanian memerlukan waktu yang lama dan berbiaya besar. Selain itu, ada berbagai tantangan seperti di jelaskan di atas. Namun, berdasarkan data FAO (2011:23), dari 104 negara di dunia yang mengembangkan program asuransi pertanian, sekitar 83 persennya telah memiliki pasar asuransi pertanian dengan tingkat penetrasi tinggi.

Tingginya tingkat penetrasi pasar asuransi pertanian, terutama di Asia Pasifik, ditemukan di negara-negara yang memiliki skema subsidi yang besar, kepesertaan bersifat wajib atas salah satu dari dua produk asuransi (misalnya Jepang untuk sereal, dan China untuk penyakit epidemi ternak) atau kepesertaan bersifat wajib bagi penerima kredit pertanian/tanaman (di India). Indikator lain yang menjelaskan prospektivitas pengembangan asuransi pertanian di suatu negara bisa juga dilihat dari meningkatnya jumlah perusahaan penyedia asuransi pertanian dan lembaga penyalurnya, meningkatnya jumlah polis asuransi pertanian, dan meningkatnya jumlah area tanam atau ternak yang terasuransikan. 


\section{METODE PENELITIAN}

Kajian ini merupakan kajian konseptual atau kajian non penelitian dimana substansi tulisan merupakan hasil pemikiran penulis atas suatu permasalahan (Alam, 2015). Metode pengumpulan data untuk memaparkan kajian ini dilakukan dengan metode dokumentasi. Metode dokumentasi adalah suatu metode pengumpulan data dengan menggunakan berbagai dokumen seperti tulisan, gambar, atau karya seseorang yang monumental (Sugiyono, 2015:240). Sumber data dalam kajian ini mencakup artikel konseptual yang relevan, hasil penelitian terdahulu, peraturan, kebijakan dan lainnya.

Metode analisis yang digunakan adalah analisis deskriptif kualitatif. Pertama, menjelaskan praktik asuransi pertanian pada beberapa negara di kawasan Asia Pasifik (China dan Jepang) serta Amerika Latin (Argentina dan Brazil) yang relatif berhasil mengembangkan program asuransi pertanian, dan perkembangan program asuransi pertanian di Indonesia. Kedua, menganalisis tantangan apa saja yang dihadapi terkait penerapan asuransi pertanian di Indonesia dan bagaimana prospek ke depannya.

\section{HASIL DAN PEMBAHASAN}

\section{Praktik Internasional Asuransi Pertanian}

Menurut FAO (2011:1), setidaknya ada 44 negara di kawasan Asia Pasifik yang concern dengan program asuransi pertanian. Dari total premi asuransi pertanian sekitar USD4 miliar yang terdistribusi di kawasan ini, China memiliki porsi 50 persen dari total premi. Kemudian, diikuti oleh Jepang (31 persen), India (11 persen), Australia (4 persen) dan Republik Korea (3 persen). Secara keseluruhan, lima pasar asuransi pertanian ini memiliki porsi 99 persen dari total premi di Asia Pasifik.

Menurut World Bank (2010:5), Kawasan Amerika Latin (Latin American Countries, LAC) meliputi 32 negara dengan luas wilayah 205 juta ha dan dihuni oleh 561 juta populasi. Dari 75 perusahaan asuransi pertanian di kawasan LAC, separuhnya ada di Argentina, Brazil dan Meksiko yang merupakan tiga pasar pertanian terbesar sekaligus sebagai tiga pasar asuransi pertanian terbesar. Ketiga negara itu membukukan premi 85 persen dari total premi kawasan LAC. Berikut ini adalah gambaran atas perkembangan asuransi pertanian di negara China, Jepang, Argentina dan Brazil.

\section{China}

Penerapan asuransi pertanian, terutama tanaman dan ternak, dimulai pada tahun 1982. Untuk mengembangkan asuransi pertanian, pemerintah melakukannya dalam dua tahap. Tahap pertama (1982-2002) ketika asuransi pertanian dikembangkan oleh People's Insurance Company of China (PICC) dan diperluas ke daerah pedesaan melalui pemerintah daerah. Pendapatan premi asuransi pertanian terbesar pada tahun 1992 sebesar USD98 juta, tetapi kemudian menurun hingga menjadi hanya USD40 juta (2002). Selama periode tersebut, kinerja pertanggungan (underwriting) PICC masih buruk.Tahap kedua dimulai dengan program asuransi pertanian bersubsidi yang baru pada tahun 2003. Pemerintah mendorong ekspansi perusahaan-perusahaan asuransi pertanian yang baru, dan pada tahun 2006-2007 menegaskan pentingnya asuransi pertanian sebagai bagian inti dari kebijakan pembangunan pertanian.

Berkembangnya asuransi pertanian di China terutama disebabkan oleh dukungan pemerintah berupa subsidi premi dan dukungan reasuransi. Di sisi lain, pemerintah tidak menyediakan subsidi untuk biaya administrasi, biaya penilaian kerugian (loss adjustment) serta biaya pendidikan dan 
pelatihan kepada perusahaan asuransi. ${ }^{1}$ Juga, belum ada undang-undang yang spesifik mengenai asuransi pertanian.

Total premi asuransi pertanian berkembang lambat selama periode 2003-2006. Namun, sejak tahun 2007, pasar asuransi pertanian mulai berkembang pesat,yang ditandai dengan meningkatnya total premi, masing-masing sebesar USD682 juta (2007), USD1,6 miliar (2008) dan USD1,96 miliar (2009). Sementara itu, subsidi premi dari pemerintah juga meningkat (2007:USD283 juta; 2008: USD900 juta dan 2009: USD1,17 miliar) sehingga rasio premi bersubsidi juga meningkat. Hal ini berpengaruh pada meningkatnya polis yang diterbitkan. Pada tahun 2007,rasio premi bersubsidi sekitar 41 persen dengan jumlah polis yang diterbitkan 51,8 juta polis. Luas lahan yang terasuransi 15,3 juta hektar (dari total 153,6 juta hektar). Untuk ternak babi yang terasuransi sebanyak 51,5 juta (atau 80 persen dari populasi babi di China). Pada tahun 2009, rasio premi bersubsidi meningkat menjadi 60 persen dengan jumlah polis sebanyak 133,8 juta polis.Selama tahun 2003-2007, kinerja keuangan industri asuransi pertanian di China memiliki rata-rata loss ratio 55 persen.

Mengingat luasnya wilayah China, maka pengembangan produk asuransi tanaman dan ternak berbasis inisiatif provinsi dan relevan dengan kondisi provinsi tersebut. Selama pengembangan asuransi tanaman dan ternak skala percontohan, porsi subsidi premi berkisar 20-100 persen, tergantung pada provinsinya. Pada tahap selanjutnya, tahun 2007, untuk subsidi premi asuransi tanaman, pemerintah pusat menyediakan subsidi 25 persen dari premi asuransi, pemerintah provinsi 25 persen, dan 50 persen sisanya dibayar petani. Tahun 2008, subsidi premi pemerintah (pusat dan provinsi) meningkat menjadi 60 persen dan 40 persen sisanya dibayar petani. Tanaman utama yang diasuransikan di China adalah jagung (maize), beras, kedelai, gandum, dan kapas.

Subsidi premi untuk asuransi ternak babi pada tahun 2007 adalah 50 persen (pemerintah pusat) dan 25 persen (pemerintah provinsi). Pada tahun 2008, porsi subsidi menjadi 50 persen (pemerintah pusat) dan 30 persen (pemerintah provinsi). Untuk asuransi sapi perah, subsidi pemerintah (pusat dan provinsi) sebesar 60 persen dan proporsinya bisa bervariasi antara pemerintah pusat dan provinsi. Tahun 2010, porsi subsidi premi asuransi tanaman oleh pemerintah maksimum menjadi 65 persen, sedangkan porsi subsidi premi untuk ternak babi tetap 80 persen. Ternak utama yang diasuransikan adalah babi ternak.

Struktur pasar asuransi pertanian China meliputi sepuluh perusahaan asuransi, yaitu tiga perusahaan asuransi khusus penyedia asuransi tanaman dan ternak (Anxin, Ancheng, Anhua) serta tujuh perusahaan asuransi lainnya yang tidak secara khusus sebagai penyedia asuransi tanaman dan/ atau ternak (Zeijiang, Hainan, Sunlight, Groupama, Guoyuan, PICC,dan China United Property Insurance Company(CUPIC)). Produk reasuransi disediakan oleh satu perusahaan reasuransi nasional, yaitu China Re. Dalam hal tertentu, pemerintah provinsi juga dapat bertindak sebagai pihak reasuransi atau co-reasuransi program-program khusus dalam hal batas reasuransi terlampaui. Sejak tahun 2008, semua asuransi pertanian disediakan oleh perusahaan swasta dan tidak ada lagi perusahaan asuransi pertanian sektor publik di China. Beberapa penyalur asuransi pertanian yang paling penting adalah asosiasi petani, koperasi dan komite desa, broker asuransi, pemasok input, bank, dan jaringan agen perusahaan asuransi.

\section{Jepang}

Beberapa regulasi spesifik terkait asuransi pertanian telah disahkan oleh pemerintah yaitu Undang-Undang Asuransi Ternak (tahun 1929), Undang-Undang Asuransi Kehutanan Nasional

\footnotetext{
${ }^{1}$ Secara umum, biaya total asuransi pertanian mulai akuisisi, administrasi, dan penilaian kerugian berkisar 20-30 persen dari premi bruto.
} 
(1937), Undang-Undang Asuransi Pertanian (1938), serta Undang-Undang Asosiasi Koperasi Pertanian (1947). Undang-undang yang disebutkan terakhir ini menjadi pilar utama reorganisasidari organisasi pertanian dan modernisasi desa-desa pertanian di Jepang. Menurut undang-undang ini, Program Kompensasi Bencana Pertanian bertujuan untuk menjaga stabilitas usaha pertanian dengan memberikan kompensasi atas kerugian petani akibat peristiwa yang tidak diharapkan, terutama pada tanaman atau ternak yang rusak akibat cuaca, penyakit, dan hama. Program ini bergantung pada prinsip solidaritas di kalangan petani. Setiap koperasi mengumpulkan dana dimana petani berkontribusi melalui pembayaran premi. Skema ini diberlakukan pada hampir semua tanaman utama.

Untuk mengembangkan asuransi pertanian tersebut, pemerintah menyediakan berbagai dukungan publik, yaitu dukungan regulasi seperti tersebut di atas, subsidi premi, subsidi atas biaya administrasi dan operasional, subsidi biaya penilaian kerugian, dukungan reasuransi, subsidi biaya R\&D dan biaya pendidikan dan pelatihan, serta dana bencana. Menurut data Departemen Pertanian, Kehutanan, dan Perikanan Jepang, periode 1990-2005 pemerintah Jepang mengalokasikan rata-rata USD640 juta setiap tahun untuk mensubsidi 50 persen dari biaya premi, serta hibah kepada federasi/koperasi USD44 juta per tahun. Dengan dana hibah tersebut, berarti pemerintah memberikan subsidi untuk biaya administrasi dan operasional, biaya penilaian kerugian dan biaya diklat bagi koperasi pertanian di Jepang. Di samping itu, pemerintah bertindak sebagai pihak reasuransi bagi seluruh skema asuransi pertanian. Angka loss ratio rata-rata pada pasar asuransi pertanian (tanaman dan ternak) adalah 94 persen selama periode 2003-2007. Sedangkan loss ratio rata-rata bagi pemerintah sebagi pihak reasuransi atas skema asuransi pertanian pada periode 2003-2005 sekitar 125 persen. Pemerintah juga menyediakan program bantuan bencana sehingga petani yang terkena bencana alam memenuhi syarat untuk memperoleh berbagai pinjaman berbunga rendah serta berhak untuk pengurangan atau pembebasanpajak.

Sifat kepesertaan (sukarela atau wajib) atas asuransi pertanian tergantung pada jenis produk dan ukuran lahan pertanian. Jenis tanaman utama yang ditentukan Undang-Undang, seperti gandum, barley dan beras,wajib diasuransikan. Namun, petani yang tidak memenuhi beberapa kriteria (misalnya minimum area yang diasuransikan) dapat memilih untuk membeli polis yang berbasis sukarela. Produk asuransi pertanian lainnya seperti asuransi ternak dan asuransi rumah kaca bersifat sukarela.Tarif premi ditetapkan pada saat koperasi/federasi membayar premi reasuransi kepada pemerintah.

Struktur pasar asuransi pertanian di Jepang bergantung pada jaringan koperasi di tingkat lokal, regional, dan nasional. Tidak ada penyalur khusus untuk petani kecil dan marjinal, kecuali melalui 300 koperasi yang ada di Jepang. Penetrasi asuransi pertanian mencapai sekitar 2,1 juta polis telah diterbitkan pada area pertanian seluas 2,0 juta hektar (mewakili 44 persen dari total luas panen tanaman utama atau 90 persen dari total lahan sereal) pada tahun 2007. Sedangkan jumlah ternak yang diasuransikan sebanyak 6,7 juta ekorpada tahun 2005. Asuransi kehutanan termasuk bisnis yang besar di Jepang mencakup area lahan 394 ribu hektar diasuransikan dengan 31 ribu polis yang diterbitkan.

\section{Argentina}

Pasar asuransi pertanian di Argentina berkembang baik dan mempunyai sejarah yang panjang. Asuransi pertanian terkonsolidasi di lima provinsi seperti Buenos Aires, Santa Fe dan Cordoba. Jenis produk asuransi tanaman di Argentina yaitu named-perildan MPCI.Hampir semua tanaman bisa menggunakan produk named-peril. Sedangkan MPCI hanya untuk kedelai, jagung, gandum, jelai, dan bunga matahari. Selain itu, ada asuransi ternak dan asuransi kehutanan. 
Dukungan sektor publik dalam rangka program asuransi pertanian meliputi dana subsidi premi, bantuan teknis dan pembelian asuransi bencana. Pemerintah provinsi berpartisipasi aktif dalam pengelolaan skema asuransi pertanian. Tahun 2009, total belanja dari lima pemprov (seperti Buenos Aires, Santa Fe dan Cordoba) sekitar USD5,5 juta (eq. Rp55 miliar, Rp10.000/USD) untuk penyediaan subsidi premi dan pembelian asuransi bencana. Pemerintah pusat menyediakan bantuan teknis (informasi dancapacity building, $\mathrm{R} \& \mathrm{D}$ produk dan pemetaan risiko) kepada pemerintah provinsi dan perusahaan asuransi. Bantuan tersebut disalurkan melalui unit pendukung teknis yaitu Agriculture Risk Office di bawah Kementerian Pertanian, Peternakan dan Perikanan. Selain itu, pemerintah pusat berencana menyusun pembentukan Sistem Asuransi Pertanian Yang Terintegrasi (SICAF). SICAF ini untuk mempercepat terbentuknya public private partnerships asuransi pertanian, yang meliputi penyediaan (1) subsidi premi asuransi pertanian, (2) partisipasi pemerintah dalam catastrophic risk layers, dan (3) informasi dan capacity building dalam pengelolaan risiko sektor pertanian. Anggaran yang dialokasikan untuk SICAF sekitar USD75 juta.

Tingkat penetrasi asuransi hujan es/hail (named-peril) mencapai 95 persen dari total area yang terasuransi dan mencapai 97 persen dari total premi pertanian di Argentina. Sedangkan produk MPCI yang diperkenalkan pada akhir 1990-an berbiaya tinggi tetapi memiliki nilai pertanggungan yang rendah sehingga tingkat penetrasinya tidak signifikan. Produk asuransi lainnya yang tingkat penetrasinya tidak signifikan adalah asuransi kehutanan dan asuransi ternak. Agen broker di perusahaan asuransi (khususnya koperasi) merupakan sumber daya paling penting dalam penyaluran asuransi hujan es. Sedangkan MPCI dan forestry, umumnya melalui broker retail dan koperasi. Ada 137 ribu polis asuransi tanaman yang diterbitkan pada 19 juta ha (50 persen dari total area yang dibudidayakan). Menurut World Bank (2010:42-43), yang menarik di negara ini adalah seorang broker bisa mengelola portfolio asuransi pertanian hingga USD15 juta.

Mengenai struktur pasar asuransi pertanian Argentina dapat dijelaskan sebagai berikut. Terdapat 26 perusahaan asuransi yang memperoleh izin untuk menjual produk asuransi pertanian. Mayoritas adalah perusahaan asuransi swasta (23 perusahaan), dan sisanya berupa koperasi dan hanya satu BUMN asuransi. Dalam kenyataannya, hanya sepuluh perusahaan asuransi yang menjual produk asuransi pertanian. Dua entitas terbesar untuk produk asuransi pertanian adalah koperasi, yang membukukan 39 persen dari total premi. Hampir semua bisnis perusahaan asuransi melakukan reasuransi ke pasar reasuransi internasional. Volume pasar asuransi terdiri dari jumlah premi USD187 juta dan liabilitas sebesar USD5.443 juta.

\section{Brazil}

Asuransi pertanian di Brazil diperkenalkan tahun 1955 oleh BUMN asuransi, Companhia Nacional do Seguro, yang beroperasi hingga pertengahan tahun 1990-an. Jenis produk asuransi pertanian meliputi asuransi tanaman (meliputi named-peril, MPCI, dan index based), asuransi ternak dan asuransi kehutanan. Polis named-peril ditawarkan untuk berbagai tanaman, perkebunan buahbuahan dan tanaman sayuran di empat provinsi (termasuk Sao Paulo). Polis MPCI ditawarkan untuk kedelai, jagung, kacang, tebu, dan gandum di sebelas provinsi (termasuk Sao Paulo). Produk MPCI ini linked dengan bank atau pinjaman pemasok input. Jenis risiko yang ditanggung seperti kebakaran, kekeringan, banjir, hujan lebat dan lainnya.

Selanjutnya, asuransi tanaman berbasis indeks (area yield index base)yang dipasarkan di provinsi Rio Grande do Sul pada tahun 1998. Kerugian bisa dibayar ketika yield rata-rata yang ditentukan Brazilian Institute of Geography and Statistics lebih rendah dari guaranteed yield, sekitar 80 persen dari actual production history di setiap kotamadya. Tanaman satu-satunya yang diasuransikan 
adalah jagung di Rio Grande do Sul. Tahun 2010, perusahaan agribisnis skala besar membeli asuransi area yield index untuk melindungi portfolio tanaman dan pertanian perusahaan.

Untuk mengembangkan asuransi pertanian, pemerintah menyediakan tiga jenis dukungan pemerintah yaitu pemberian subsidi premi, dukungan terhadap risiko bencana, dan dukungan terhadap petani komersil. Sejak tahun 2005, pemerintah pusat dan pemerintah provinsi memberikan subsidi premi. Kisaran subsidi premi dari pemerintah pusat 30 - 60 persen dari biaya premi, tergantung pada jenis tanaman. Alokasi subsidi premi dari pemerintah sekitar USD164 juta (pemerintah pusat USD149 juta dan beberapa pemprov sebesar USD15 juta) pada tahun 2009. Pempus menyediakan subsidi premi melalui Kementan tapi tidak menetapkan kriteria untuk pemberian subsidi tersebut. Dukungan lain dari pemerintah pusat adalah berbagi sebagian risiko bencana yang dihadapi produksi pertanian dalam skemaPublic Private Partnerships, Rural Catastrophe Fund. Dana ini menyediakan stoploss coverage untuk perusahaan asuransi swasta yang menawarkan asuransi pertanian. Dana ini dibiayai oleh industri asuransi, entitas pemerintah, Brazilian Reinsurance Institute, dan perusahaan reasuransi internasional. Selain itu, terkait dengan asuransi pertanian pada petani komersial hasil kerjasama pemerintah-swasta(PPP), pemerintah telah mengimplementasikan PROAGRO (Brazilian Guarantee Program) dan SEAF (Insurance for Family Agriculture).

Asuransi tanaman merupakan produk utama (92 persen dari total premi), sedangkan porsi delapan persen sisanya berupa asuransi ternak dan asuransi kehutanan. Walaupun demikian, tingkat penetrasi semua produk asuransi relatif rendah. Tahun 2009, asuransi tanaman telah diterapkan terhadap sekitar 6,7 juta hektar (10 persen dari total area yang dibudidayakan). Sedangkan untuk asuransi ternak hanya terhadap 51 ribu ternak yang terasuransikan (kurang 1 persen dari total ternak nasional). Untuk asuransi kehutanan dilakukan terhadap 68 ribu hektar dari 5 juta hektar hutan (di bawah 2 persen). Untuk lembaga penyalur asuransi pertanian tergantung pada jenis lini bisnis. Untuk MPCI, penyalur utamanya adalah bank, lembaga keuangan, koperasi dan pemasok input. Untuk asuransi hail, asuransi ternakdan asuransi kehutanan, penyalur utamanyaadalah broker retail.Menurut World Bank (2010:44), yang menarik di Brazil adalah munculnya kemitraan yang dibangun sebuah perusahaan asuransi, Alianca do Brasil dengan sebuah bank, Banco do Brasil, yang mempunyai kelolaan portfolio asuransi pertanian terbesar di kawasan LAC yaitu USD150 juta. Tingginya portofolio tersebut dikarenakan produk asuransi tersebut di-linked dengan kredit pedesaan dan disalurkan hanya melalui cabang Banco do Brasil.

Pasar asuransi pertanian Brazil memiliki pertumbuhan pasar yang sangat cepat karena dukungan keuangan pemerintah pusat dan pemprov. Struktur pasar asuransi Brazil mencakup sembilan perusahaan asuransi swasta yang menawarkan asuransi pertanian. Perusahaan asuransi utama menjalinkemitraan dengan bank nasional sehingga mampu membukukan pendapatan premi 51 persen dari total premi di pasar. Semua bisnis asuransi pertanian di Brazil di-reasuransikan ke perusahaan reasuransi internasional dan reasuransi lokal (Brazilian Reinsurance Institute). Volume pasar asuransi meliputi USD255,9 juta premi dan liabilitas mencapai USD5.806 juta.

\section{Perkembangan Program Asuransi Pertanian di Indonesia}

Program asuransi pertanian di Indonesia dikaji oleh Kementan sejak tahun 1982 (Nurmanaf et al, 2007:2; Sumaryanto dan Nurmanaf, 2007:90; PASEKP, 2009:17; Boer, 2012:3; Supartoyo dan Kasmiati, t.t.:3).Kelompok Kerja Departemen Pertanian (Deptan) dalam rangka penerapan asuransi pertanian yang dibentuk pertama kali tahun 1982 telah gagal melaksanakan tugasnya. Selanjutnya, Deptan membentuk Pokja baru tahun 1985 dan juga tahun 1999 dengan mengikutsertakan Balitbang Pertanian. 
Pada tahun 2000, ujicoba asuransi pertanian dinilai sukses yang pelaksanaannya dikombinasikan dengan asuransi jiwa. Ujicoba dilakukan melalui kerjasama pemerintah provinsi Sumut dengan Bumida dan BPD Sumut. Namun, kinerja tim tidak sukses untuk mengembangkan dalam skala besar, berhenti hanya pada skala pilot. Tahun 2008 kementan mengembangkan model asuransi untuk ternak sapi dan tanaman padi dengan nilai premi 3,5 persen dari harga sapi dan biaya input per musim tanam di Jawa namun perusahaan asuransi tidak ada yang berminat (Pasaribu et al, 2009 dalam Boer, 2012:4).

Ujicoba asuransi pertanian tahun anggaran 2008-2009 oleh Pusat Pembiayaan Pertanian Ditjen Prasarana dan Sarana Pertanian Kementan dapat dijelaskan sebagai berikut. Ujicoba dilakukan terhadap komoditas padi dan ternak sapi di beberapa daerah. Asuransi usahatani padi (AUTP) di kabupaten Semarang diikuti oleh 600 petani. Preminya sebesar 3,5 persen dari biaya produksi/ha/ musim tanam, yang dibayar oleh Pusat Pembiayaan Pertanian, Kementan. Nilai klaim sebesar nilai input. Perusahaan asuransi swasta berkontribusi dalam ujicoba ini. Dalam ujicoba, terjadi gagal panen karena serangan OPT senilai Rp554juta dengan luas lahan 100 ha. Selanjutnya, ujicoba asuransi ternak di kabupaten Cirebon diikuti oleh 49 peternak untuk mengasuransikan 49 sapi. Asuransi ini meng-cover ternak yang meninggal karena sakit dan hilang karena dicuri. Total nilai pertanggungan sekitar Rp600juta. Asuransi ternak di kabupaten Boyolalidiikuti sebanyak 97 sapi milik 97 peternak. Total nilai pertanggungan Rp1.118 juta (sekitar Rp11,5juta/sapi) Besarnya premi 3,5 persen/ternak/tahun dari nilai pembelian ternak. Dalam ujicoba ini melibatkan perusahaan asuransi swasta. Hasil ujicoba ini adalah terjadinya klaim atas sapi yang meninggal karena sakit senilai Rp11,5 juta. Tahun 2009, ujicoba skim asuransi padi di kabupaten Serang, Banten. Skenario yang dikembangkan adalah dengan melibatkan asuransi swasta masuk sebagai penanggung premi asuransi dengan imbalan hasil pertanian padi dijual ke perusahaan swasta tersebut. Petani diduga memilih skenario ini karena ada kepastian harga dan pasar, dan petani sendiri tidak dibebankan membayar premi asuransi.

Ujicoba asuransi pertanian TA2008-2009 oleh Pusat Penelitian Sosial Ekonomi dan Kebijakan Pertanian (PPSEKP) Balitbang, Kementan dapat dijelaskan sebagai berikut. Kajian dilakukan terhadap komoditas padi di kabupaten Simalungun Sumatera Utara dan kabupaten Tabanan, Bali. Pendanaan kajian 2008 dibiayai PPSEKP Balitbang Deptan dan FAO sedangkan 2009 dibiayai oleh kerjasama Kementan dan Kemendiknas. Rekomendasi kajian adalah perlunya melibatkan petani dan pemda dalam mengembangkan model asuransi sesuai dengan kondisi daerah masingmasing.Pemkab Simalungun dan Pemkab Tabanan menyatakan kesiapan untuk melaksanakan skim asuransi usaha tani padi (Pasaribu et al, 2010:10; Boer, 2012:4).

Boer (2012:4-5) menyebutkan bahwa kementan telah membentuk Konsorsium Penjamin Asuransi Pertanian dengan anggota pemda, koperasi petani dan perusahaan asuransi. Kementan juga membentuk Pokja Asuransi Komunitas Pertanian bekerjasama dengan PT Asuransi Bumi Putera guna mengembangkan sistem asuransi pertanian dalam skala luas. Di sisi lain, pihak kementan memandang asuransi indeks iklim merupakan salah satu instrumen alternatif untuk melindungi kepentingan petani tetapi jenis asuransi ini masih dalam taraf kajian. Terkait dengan asuransi indeks iklim, hasil riset International Finance Corporation dan Kemitraan Indonesia Australia (2010) terhadap tanaman jagung di wilayah Indonesia Timur, hasil riset IPB dengan IRI Columbia Uiversity USA, serta hasil riset IPB dengan Balitbang Kementan atas tanaman padi di Indramayu menunjukkan bahwa produk asuransi ini berpotensi untuk dikembangkan.

Selanjutnya, ujicoba asuransi pertanian TA 2012-2014 oleh PPSEKP Balitbang, Kementan. Berdasarkan penjelasan PT. Asuransi Jasa Indonesia (2014), uji coba ini dilaksanakan di Jawa Timur dan Sumatera Selatan dengan melibatkan PT. Asuransi Jasindo, PT. Petrokimia Gresik, PT. Pupuk Kujang Cikampek, dan PT. Pupuk Sriwijaya Palembang pada Musim Tanam I (Oktober 2012 s.d 
Maret 2013) dan Musim Tanam II (Oktober 2013 s.d Maret 2014). Dalam uji coba ini, PT. Asuransi Jasindo bertindak selaku perusahaan asuransi (penanggung). Sedangkan ketiga BUMN pupuk bertindak selaku kontributor melalui program CSR-nya memberikan bantuan premi bagi petani sebagai tertanggung. Kementan bertindak selaku fasilitator melalui aparat di daerah. BUMN pupuk menyediakan dana untuk pembayaran 80 persen premi asuransi sedangkan petani hanya membayar 20 persen dari premi. Sebagai peserta asuransi, petani diwajibkan untuk menerapkan rekomendasi teknis/tata kelola pertanian yang baik dalam melakukan usaha taninya, misalnya pemupukan tanaman menggunakan pupuk yang berimbang, agar saat terjadi gagal panen klaim asuransi dapat dicairkan. Dalam ujicoba ini, suku premi dan nilai pertanggungan diasumsikan 3 persen dan Rp6 juta/ha/MT sehinggabiaya premi yang harus dibayar sebesar Rp180 ribu/ha/MT. Sedangkan maksimal luas lahan yang bisa diasuransikan adalah 2 ha. Klaim akan dibayarkan saat terjadi gagal panen dengan kriteria terjadi kerusakan lebih dari 75 persen dari luas area lahan pertanian yang diasuransikan. Nilai pertanggungan sebesar Rp6 juta dinilai mewakili rata-rata biaya produksi. Sedangkan franchise dengan batas 75 persen ditetapkan dengan maksud untuk efisiensi dalam penanganan klaim dan asumsi bahwa kerusakan dibawah prosentase tersebut dinilai masih memberikan hasil cukup bagi petani penggarap.

Realisasi pada Musim Tanam I, telah diterbitkan 42 polis dengan realisasi lahan seluas 623,12 ha dari target 3.000 ha. Rinciannya 25 polis untuk lahan seluas 470,87 ha (Jombang, Jawa Timur) dan 17 polis untuk lahan seluas 152,25 ha (Sumatera Selatan). Dalam uji coba ini, penanggung menyelesaikan klaim Rp961.080.000 sedangkan premi yang diterima hanya Rp112.161.000, sehingga terjadi loss ratio 857 persen. Penyebab terbesar terjadinya klaim adalah akibat banjir, sedangkan penyebab yang lain adalah serangan hama penyakit (tikus dan blast).Untuk Musim Tanam II mencakup lahan seluas total 2.202,87 ha di dua provinsi (1.436,62 ha di Jawa Timur dan 766,25 ha di Sumatera Selatan), loss ratio sebesar 68 persen berdasarkan jumlah klaim yang dibayarkan Rp267.000.000 dan premi yang diterima sebesar Rp396.516.160. Penyebab klaim adalah serangan tikus (di Sumatera Selatan dan Jawa Timur) serta bencana banjir (di Sumatera Selatan).

Di sisi lain, asuransi pertanian yang diujicobakan di Karawang belum menarik minat petani (Tabel 1). Berdasarkan penjelasan PT Pupuk Kujang Cikampek (2014), para petani belum tertarik dikarenakan adanya pembayaran premi serta persepsi petani yang menganggap daerahnya tidak berisiko puso atau terkena wabah lainnya.

Tabel 1.

Pelaksanaan Ujicoba AUTP pada Musim Tanam I, 2012

\begin{tabular}{|c|c|c|c|c|c|c|}
\hline No. & Operator & Provinsi & Kabupaten & $\begin{array}{c}\text { Target } \\
\text { (ha) }\end{array}$ & $\begin{array}{l}\text { Realisasi } \\
\text { (ha) }\end{array}$ & $\begin{array}{c}\text { Selisih } \\
\text { (ha) }\end{array}$ \\
\hline 1 & PSP & $\begin{array}{c}\text { Sumatera } \\
\text { Selatan }\end{array}$ & $\begin{array}{l}\text { OKU } \\
\text { Timur }\end{array}$ & 1000 & 152.25 & 847.75 \\
\hline \multirow[t]{2}{*}{2} & \multirow[t]{2}{*}{ PKG } & \multirow[t]{2}{*}{ Jawa Timur } & Tuban & 750 & 320.00 & 430.00 \\
\hline & & & Gresik & 250 & 150.87 & 99.13 \\
\hline 3 & PKC & Jawa Barat & Karawang & 1000 & 0 & 1000 \\
\hline \multicolumn{4}{|c|}{ Jumlah } & 3000 & 623.12 & 2376.88 \\
\hline
\end{tabular}

Sumber: PT Pupuk Indonesia Holding Company (2014).

Keterangan: PSP= Pupuk Sriwijaya Palembang; PKG= Petrokimia Gresik; PKC= Pupuk Kujang Cikampek

Selain berbagai ujicoba di atas, menurut FAO (2011:158), selama beberapa dekade perusahaan kehutanan dan perkebunan dan pulp kertas besar telah membeli asuransi kebakaran hutan (suatu produk asuransi yang termasuk bagian dari asuransi pertanian) dari perusahaan asuransi lokal. Dalam 
struktur pasar asuransi Indonesia, terdapat lebih dari 150 perusahaan asuransi jiwa dan non-jiwa yang terdaftar dengan total premi pasar sekitar USD3,8 miliar (1,4 persen dari PDB). Untuk asuransi jiwa tingkat penetrasi pasar adalah 0,8 persen dari PDB dan asuransi non-jiwa 0,6 persen dari PDB. Saat ini tidak ada perusahaan yang spesialis dalam asuransi pertanian. Volume premi pada tahun 2009 termasuk asuransi kehutanan diprediksi sekitar USD1 juta.

Dalam perkembangannya, pemerintah telah menerbitkan Undang-Undang Nomor 19 Tahun 2013 tentang Perlindungan dan Pemberdayaan Petani. UU tersebut mengatur bahwa (1) asuransi pertanian merupakan bagian dari strategi untuk melindungi petani; (2)yang dimaksud petani meliputi a) petani penggarap tanaman pangan yang tidak memiliki lahan usaha tani dan menggarap paling luas dua hektar, b) petani yang memiliki lahan dan melakukan usaha budidaya tanaman pangan pada lahan paling luas dua hektar, serta c) petani hortikultura, pekebun atau peternak skala usaha kecil;(3) asuransi tersebut diharapkan dapat melindungi petani dari kerugian gagal panen akibat dari bencana alam, serangan Organisme Pengganggu Tanaman (OPT), wabah penyakit hewan menular, dampak perubahan iklim dan risiko lainnya; (4) sesuai dengan kewenangannya, pemerintah pusat dan pemerintah daerah memfasilitasi setiap petani menjadi peseta asuransi diantaranya adalah pemberian bantuan pembayaran premi; (5) bantuan premi tersebut berasal dari APBN dan/atau APBD, yang dibayarkan sampai dinyatakan oleh pemerintah dan pemerintah daerah bahwa petani mampu membayar preminya sendiri; dan (6) terkait dengan pengembangan asuransi pertanian, pemerintah pusat/pemda dapat melakukan penugasan kepada BUMN/BUMD asuransi.

Pada tahun 2015, pemerintah melalui anggaran Kementan telah mengalokasikan dana Rp150 miliar untuk implementasi program asuransi pertanian. Dengan demikian, Pengguna Anggaran (PA) dijabat oleh Menteri Pertanian dan Kuasa Pengguna Anggaran (KPA) dijabat oleh salah satu pejabat unit eselon I Kementan.

\section{Beberapa Tantangan Penerapan Asuransi Pertanian di Indonesia}

Sebagaimana dijelaskan di atas, World Bank (2010:77) mengelompokkan berbagai tantangan dalam rangka implementasi program asuransi pertanian menjadi empat jenis tantangan, yaitu tantangan institusional, finansial, teknis dan operasional. Sebagai negara pemula (start up), berbagai tantangan yang dihadapi pemerintah Indonesia dalam rangka penerapan program asuransi pertanian setidaknya juga meliputi empat tantangan tersebut.

Tantangan institusional meliputi pertama, bagaimana memperkuat kerangka institusi. Pilihan model untuk mengembangkan asuransi pertanian (fully intervened system, public-private partnership atau market based) akan berdampak pada institusi mana saja yang terlibat dalam pengembangan asuransi pertanian, termasuk institusi yang bertindak sebagai Kuasa Pengguna Anggaran (KPA). Kemudian, apakah BUMN asuransi akan memperoleh penugasan sebagai penyedia dan penyalur asuransi pertanian, bagaimana mendorong perusahaan asuransi swasta berperan dalam pengembangan asuransi pertanian, bagaimana mekanisme koordinasi pembagian porsi terkait bantuan pembayaran premi antara pemerintah pusat dan pemerintah daerah. Kedua, bagaimana memperkuat kerangka hukum secara memadai, misalnya jenis asuransi pertanian apa dan jenis tanaman atau ternak apa yang diprioritaskan memperoleh bantuan premi, berapa lama pemberian subsidi premi, bagaimana sifat kepesertaan pada petani (wajib atau sukarela), apakah petani penerima kredit tanaman diwajibkan membeli asuransi tanaman sebagai syarat akses kredit sekaligus sebagai jaminan pelunasan kredit, dan lain sebagainya. Ketiga, perlukah pemerintah mengintegrasikanprogram asuransi pertanian dengan produk dan layanan lain yang diterima petani (subsidi pupuk, subsidi benih, dan bantuan sosial). 
Selanjutnya, tantangan keuangan meliputi bagaimana pemerintah pusat (secara terpisah maupun bersama-sama dengan pemda) menyediakan berbagai dukungan finansial untuk mengembangkan asuransi pertanian. Dukungan finansial ini bisa berupa dukungan yang minimal (hanya berupa penyediaan subsidi premi) sampai pada dukungan maksimal (berupa dukungan kerangka hukum yang spesifik, subsidi premi, subsidi biaya administrasi dan operasional, subsidi penilaian kerugian (loss adjustment), dukungan reasuransi, subsidi biaya $R \& D^{2}$ dan biaya pendidikan dan pelatihan, serta dana bencana). Apabila pemerintahmemberikan dukungan yang maksimal, sebagaimana dilakukan pemerintah Jepang, pertanyaannya adalah seberapa besar dana yang dialokasikan oleh APBN/APBD dan bagaimana dengan keberlanjutan program asuransi pertanian tersebut di masa mendatang.

Ketiga, tantangan teknis yang dihadapi terkait dengan penilaian atas eksposur risiko pada sektor pertanian dan bagaimana mendesain model risikonya guna menentukan kerugian maksimum. Kedua hal kunci ini memungkinkan pemerintah mengembangkan kebijakan pengelolaan risiko pertaniansecara memadai. Berbagai upaya pengendalian atas akumulasi risiko pertanian yang sesuai seharusnya bisadiatasi jika tujuannya adalah memperluas asuransi pertanian bagi aktivitas pertanian dengan eksposur risiko yang tinggi seperti tanaman yang bernilai tinggi, budidaya ikan dan perkebunan. Penilaian atas risiko produksi pertanian yang sesuai dan desain produk asuransi pertanian yang wajar secara aktuaria tergantung pada ketersediaan data produksi pertanian, pemetaan daerah risiko dan data cuaca. Terkait dengan hal itu, apakah pemerintah harus berinvestasi pada infrastruktur dan layanan informasi cuaca dan pertanian yang lebih baik, misalnya dengan menyusun database nasional dan menyediakan database ini untuk semua perusahaan asuransi komersial swasta yang tertarik, baik bebas biaya maupun dengan tarif tertentu. Selain itu, apakah pemerintah perlu memainkan peran penting untuk meningkatkan kesadaran petani, mengadakan lokakarya pengembangan kapasitas dan program pelatihan teknis untuk staf perusahaan-perusahaan asuransi.

Selanjutnya, tantangan yang bersifat operasional meliputi pengembangan prosedur operasionalasuransipertanian yang kompleks dan perlu keahlian khusus. Fokusnya adalah bagaimana membuat produk asuransi pertanian yang standar internasional (terkait dengan pertanggungan, syarat dan ketentuan polis serta prosedur penilaian kerugian), tapi mudah diterapkan dan berbiaya relatif murah. Produk inilah yang diperlukan bila tujuannya untuk petani kecil.

Berbagai tantangan sebagaimana diuraikan di atas memerlukan penyelesaian dengan cepat dan cermat. Cepat dalam arti agar amanat UU Nomor 19 Tahun 2013 tentang program asuransi pertanian ini bisa segera terlaksana dalam rangka untuk melindungi pendapatan petani. Cermat dalam arti bahwa setiap tantangan di atas juga penting untuk diklasifikasikan dari sisi dimensi waktu penyelesaiannya (jangka pendek, menengah dan panjang) sehingga pelaksanaan program asuransi pertanian ini dapat terus berkelanjutan.

Dalam jangka pendek, beberapa hal yang dapat dilaksanakan diuraikan sebagai berikut. Pertama, menetapkan model fully intervened system (sektor publik) sebagai model pengembangan asuransi pertanian. Argumennya sama dengan yang dilakukan oleh negara-negara lain pada saat memulai pelaksanaan program asuransi pertanian yaitu (1) belum adanya infrastruktur asuransi di daerah pedesaan dan juga jasa asuransi pertanian sektor swasta, (2) tingginya biaya fase awal pengembangan produk asuransi pertanian, (3) adanya kendala kapasitas pihak reasuransi untuk menanggung risiko sistemik dalam produksi pertanian, (4) tingginya biaya administrasi asuransi pertanian, dan (5) munculnya masalah kemampuan bayar disebabkan tingginya biaya premi asuransi pertanian.

${ }^{2}$ Dukungan ini untuk membiayai R\&D produk asuransi pertanian yang inovatif atau R\&D produk baru untuk menggantikan produk eksisting yang tidak sesuai dengan permintaan pasar. 
Konsekuensinya adalah pemerintah perlu mendukung penuh berbagai subsidi untuk penerapan asuransi pertanian. Kedua, mengidentifikasi para pihak yang terlibat dan apa perannya masingmasing. Ketiga, menyediakan database petani, data produksi pertanian, dan pemetaan daerah risiko bencana dan gagal panen. Keempat, menyusun dokumen perencanaan, termasuk roadmap yang reliable dan valid tentang pengembangan program asuransi pertanian. Dengan adanya roadmap, dapat diidentifikasi jenis kegiatan apa saja yang akan dilakukan, kegiatan apa saja yang sedang/ sudah dilakukan dan apa yang belum dilaksanakan. Kelima, menyusun tata kelola dan pedoman monitoring evaluasi atas implementasi program asuransi pertanian, termasuk bagaimana melakukan penilaian atas eksposur risiko sektor pertanian dan menyusun model risikonya. Keenam, menyediakan dana subsidi premi, dukungan reasuransi dan dana sosialisasi program oleh pemerintah pusat secara prudent walaupun di beberapa negara ada sharing bantuan premi antara pemerintah pusat dan provinsi. Dukungan reasuransi diperlukan ketika terjadi loss ratio yang tinggi yang berdampak pada kinerja keuangan BUMN penugasan. Ketujuh, penunjukkan unit eselon I Kementan sebagai $\mathrm{KPA}^{3}$ karena dananya dialokasikan dalam anggaran kementan. Kedelapan, melakukan sosialisasi program asuransi pertanian secara meluas. Kesembilan, memberi penugasan kepada BUMN asuransi untuk menyalurkan asuransi pertanian berdasarkan database petani di atas. Terkait penunjukkan KPA, sosialisasi program dan penugasan BUMN, pada tahun 2015 ketiga hal tersebut sudah dilaksanakan.

Tantangan lainnya seperti perlunya mengevaluasi efektivitas model fullyintervened daripada model lain (PPP atau market oriented), mendorong pemprov untuk sharing penyediaan subsidi premi asuransi pertanian, mengintegrasikan asuransi pertanian dengan berbagai layanan sektor pertanian, dan penyusunan Undang Undang asuransi pertanian secara spesifik (seperti dilakukan oleh Jepang, Philippina, dan Bolivia), bisa diselesaikan dalam jangka menengah dan panjang.

Sebagai ilustrasi, untuk menuntaskan masalah penyediaan bantuan pembayaran premi yang berasal dari APBN dan/atau APBD, pemerintah pusat cq. Kementan memerlukan waktu yang cukup memadai untuk menyosialisasikan tentang pembagian porsi subsidi premi kepada seluruh pemerintah daerah. Argumennya adalah (1) kesepakatan atas pendanaan bersama tersebut memerlukan komunikasi yang intensif antara pemerintah pusat dan pemerintah daerah, serta perlu adanya payung hukum, setidaknya Peraturan Menteri Keuangan, dan (2) sosialisasi atas program asuransi pertanian ini belum dilakukan secara masif ke para pemangku kepentingan, termasuk ke pemda-pemda. Oleh karena itu, apabila program asuransi pertanian segera diterapkan, dalam jangka waktu pendek (12 tahun) bantuan pembayaran premi sebaiknya disediakan oleh APBN terlebih dahulu. Diharapkan dalam jangka waktu tersebut, terjadi komunikasi yang intens dengan pemda-pemda yang memiliki sentra pertanian dan pada akhirnya muncul kesediaan dan komitmen dari pemda untuk menyediakan pendanaan bersama terkait bantuan pembayaran premi asuransi pertanian.

Selama ini, terdapat dua pola pendanaan bersama antara pemerintah pusat dan pemerintah daerah, yaitu (1) pola Dana Alokasi Khusus (DAK), Hibah atau Pinjaman Luar Negeri; dan (2) pola pendanaan urusan bersama pusat dan daerah untuk penanggulangan kemiskinan melalui Program Nasional Pemberdayaan Masyarakat (PNPM) Perdesaan dan Perkotaan. Pada pola pertama, pemerintah daerah menyediakan dana (disebut dana pendamping) sebesar 10 persen dari alokasi DAK. Pada pola kedua, dana yang disediakan oleh pemerintah daerah bervariasi tergantung pada besarnya alokasi dana dari APBN. Besarnya alokasi dana dari APBN mempertimbangkan beberapa faktor, meliputi kemampuan keuangan negara, indeks fiskal dan kemiskinan daerah, serta indikator teknis.

${ }^{3}$ Mengacu pada Peraturan Pemerintah Nomor 45 Tahun 2013 Pasal 4 ayat (4), Pasal 8 dan Pasal 10. 
Untuk memperbesar space pendanaan dari APBN untuk penyediaan bantuan pembayaran premi asuransi pertanian, pemerintah perlu mengkaji ulang mekanisme penyediaan subsidi pupuk dan subsidi benih. Rasionalitasnya adalah kedua subsidi tersebut diberikan untuk kepentingan petani melalui BUMN pupuk dan penyedia benih. Mekanisme seperti ini berpotensi untuk tidak tepat sasaran, padahal alokasi dananya mencapai puluhan triliun rupiah dan cenderung meningkat tajam dalam beberapa tahun terakhir ini.

\section{Prospek Pelaksanaan Asuransi Pertanian}

Pelaksanaan asuransi pertanian di Indonesia masih pada tahap permulaan. Beberapa hal yang sudah dilakukan pemerintah untuk mendukung pelaksanaan asuransi pertanian diantaranya dukungan regulasi dan kebijakan (UU Nomor 19 Tahun 2013, RPJMN 2015-2019 dan peraturan kementerian teknis), dukungan subsidi premi yang dialokasikan dalam APBN dan sosialisasi program.

Undang-Undang Nomor 19 Tahun 2013 sudah mengatur mengenai definisi asuransi pertanian, petani penerima subsidi premi asuransi pertanian, kewajiban pemerintah pusat dan pemerintah daerah untuk mengalokasikan bantuan premi dari APBN dan/atau APBD, serta penugasan kepada BUMN/ BUMD asuransi. Sementara itu, Bappenas (2014:6-148) menyebutkan asuransi pertanian sebagai salah satu langkah pemerintah melakukan perlindungan kepada petani yang mengalami gagal panen dalam rangka peningkatan produksi beberapa komoditas pangan yang masuk dalam sasaran kedaulatan pangan tahun 2015-2019. Komoditas itu adalah padi (2014: 70,6 juta ton menjadi 2019: 82 juta ton), jagung (2014: 19,1 juta ton menjadi 2019: 24,1 juta ton) serta kedelai (2014: 0,9 juta ton menjadi 2019: 2,6 juta ton). Dukungan keuangan untuk pemberian subsidi premi pun terus berlanjut di APBN. Namun, kondisi demikian belum bisa mendeskripsikan apakah pelaksanaan asuransi pertanian di Indonesia sudah memiliki prospek yang baik.

Di bagian tinjauan pustaka dipaparkan bahwa tingkat prospek pengembangan asuransi pertanian di suatu negara dapat dilihat dari tingkat penetrasi pasar asuransi pertanian, jumlah perusahaan penyedia asuransi pertanian dan lembaga penyalurnya, jumlah polis asuransi pertanian, dan luas area tanam atau jumlah ternak yang terasuransikan. Dengan demikian, pengembangan asuransi pertanian dinilai semakin prospektif apabila tingkat penetrasi pasar asuransi pertanian semakin tinggi, semakin meningkatnya jumlah perusahaan penyedia dan/atau penyalur polis asuransi pertanian, semakin meningkatnya jumlah polis, semakin bertambahnya luas area tanam dan semakin meningkatnya jumlah ternak yang terasuransikan.

Agar implementasi asuransi pertanian di Indonesia memiliki prospek yang baik, beberapa langkah yang perlu dilakukan pemerintah adalah pertama, meningkatkan alokasi dana implementasi asuransi pertanian dalam APBN secara bertahap. Dana ini digunakan untuk pemberian subsidi premi, sosialisasi, dukungan reasuransi serta dukungan dana bencana. Alokasi dana bencana bertujuan agar asuransi pertanian diimplementasikan bersama-sama dengan kebijakan pengurangan risiko bencana. Hal ini perlu dilakukan karena sebagian besar wilayah Indonesia termasuk wilayah rawan bencana sehingga asuransi pertanian berpotensi gagal mengurangi risiko jika diterapkan tanpa didukung dengan kebijakan pengurangan risiko bencana. Kedua, menyusun aturan teknis yang diantaranya mengatur kepesertaan asuransi pertanian bersifat wajib dan jenis tanaman yang diprioritaskan untuk diasuransikan. Langkah ini dapat meningkatkan jumlah polis asuransi pertanian dan luas area tanam yang terasuransikan. Ketiga, mendorong Otoritas Jasa Keuangan dan asosiasi perusahaan asuransi dalam rangka pengembangan asuransi pertanian untuk memberikan kemudahan perizinan bagi perusahaan asuransi swasta yang berkomitmen, serta menyediakan dana pelatihan dan capacity building bagi perusahaan asuransi swasta tersebut. Langkah ini dapat meningkatkan 
jumlah perusahaan asuransi yang berperan dalam penyediaan dan penyaluran asuransi pertanian, yang pada akhirnya dapat meningkatkan penetrasi pasar asuransi. Keempat, mendorong dan memberi penugasan kepada BUMN asuransi sebagai penyedia dan penyalur asuransi pertanian serta berperan sebagai lembaga reasuransi. Dukungan dana reasuransi diperlukan ketika terjadi loss ratio yang tinggi yang berdampak pada kinerja keuangan perusahaan asuransi. Fungsi reasuransi dapat dilakukan oleh BUMN yang memperoleh penugasan. Kelima, mendorong pemerintah daerah yang memiliki sentra pertanian untuk berkomitmen memajukan sektor pertanian dengan cara penyediaan dana subsidi premi porsi pemda dalam APBD, intensif menyosialisasikan program asuransi pertanian, serta memfasilitasi setiap petani maupun kelompok petani menjadi peserta asuransi. Pola pendanaan bersama antara pemerintah pusat dan pemerintah daerah selama ini sudah tersedia, yaitu pola DAK maupun pola PNPM. Keenam, di masa mendatang, mengkaji pengintegrasian antara program asuransi pertanian dengan layanan sektor pertanian yang diterima petani (pupuk bersubsidi, benih bersubsidi, dan bansos). Hal ini dilakukan dalam rangka keberlanjutan program asuransi pertanian yang tentu akan membutuhkan dana yang semakin besar seiring dengan bertambahnya jumlah polis asuransi pertanian yang diterbitkan.

Dengan adanya beberapa langkah di atas, diharapkan penerapan asuransi pertanian semakin berkembang dan meningkatkan penetrasi pasar asuransi pertanian. Meningkatnya penetrasi pasar mengindikasikan program asuransi pertanian semakin prospektif di Indonesia.

Selain itu, meningkatnya penetrasi pasar diharapkan dapat menguntungkan berbagai pihak. Pertama, kesadaran petani atas risiko gagal panen semakin tinggi, manajemen usaha pertanian semakin terkelola dengan baik,produksi dan pendapatan petani semakin bertambah, dan pada akhirnya bisa mengurangi ketergantungan petani pada bantuan permodalan dari pihak lain (bank, rentenir). Kedua, bagi industri asuransi, penerapan asuransi pertanian dapat meningkatkan kapasitas industri (adanya pembukaan kantor cabang baru di berbagai daerah, penambahan pegawai, peningkatan kompetensi bidang asuransi pertanian), serta meningkatkan tingkat penetrasi pasar asuransi (jumlah klien asuransi terhadap jumlah populasi dan kontribusi sektor asuransi terhadap PDB). Bagi pemerintah daerah dan pusat, meningkatnya kegairahan petani dalam produksi tanaman pangan akan berdampak pada tercapainya sasaran ketahanan pangan daerah dan nasional, serta dapat meningkatkan kontribusi sektor pertanian baik terhadap PDB daerah maupun PDB nasional.

\section{E. PENUTUP}

Dari sisi ekonomi dan sosial, sektor pertanian merupakan salah satu sektor yang penting bagi Indonesia. Namun, sektor pertanian menghadapi berbagai risiko yang dapat berdampak pada berfluktuasinya pendapatan para petani. Terkait dengan hal ini, melalui UU Nomor 19 Tahun 2013, pemerintah berupaya melindungi petani, salah satunya melalui penerapan asuransi pertanian.

Merujuk pada pengalaman panjang penerapan asuransi pertanian di banyak negara kawasan Asia Pasifik dan Amerika Latin dan merujuk pada kondisi obyektif Indonesia, ternyata tantangan yang dihadapi sangat kompleks. Berbagai tantangan tersebut meliputi tantangan institusional, finansial, teknis dan operasional. Berbagai tantangan ini sebaiknya diselesaikan berdasarkan dimensi waktu (pendek, menengah dan panjang) sesuai dengan kompleksitas tantangan dan urgensinya.

Agar implementasi asuransi pertanian di Indonesia memiliki prospek yang baik, beberapa langkah yang perlu dilakukan pemerintah adalah (1) meningkatkan alokasi dana implementasi asuransi pertanian dalam APBN secara bertahap, (2) menyusun aturan teknis yang diantaranya mengatur kepesertaan asuransi pertanian bersifat wajib, (3) mendorong Otoritas Jasa Keuangan dan asosiasi perusahaan asuransi dalam rangka pengembangan asuransi pertanian untuk memberikan kemudahan 
perizinan bagi perusahaan asuransi swasta yang berkomitmen, serta menyediakan dana pelatihan dan capacity building, (4) memberi penugasan kepada BUMN asuransi sebagai penyedia dan penyalur asuransi pertanian serta berperan sebagai lembaga reasuransi, (5) mendorong pemerintah daerah yang memiliki sentra pertanian untuk berkomitmen memajukan sektor pertanian dengan cara penyediaan dana subsidi premi porsi pemda dalam APBD, intensif menyosialisasikan program asuransi pertanian, serta memfasilitasi setiap petani maupun kelompok petani menjadi peserta asuransi, (6) mengkaji pengintegrasian antara program asuransi pertanian dengan layanan sektor pertanian yang diterima petani (pupuk bersubsidi, benih bersubsidi, dan bansos).

Dengan adanya beberapa langkah di atas, diharapkan penerapan asuransi pertanian semakin berkembang dan meningkatkan penetrasi pasar asuransi pertanian. Meningkatnya penetrasi pasar mengindikasikan program asuransi pertanian semakin prospektif di Indonesia.

Meningkatnya penetrasi pasar diharapkan dapat menguntungkan berbagai pihak. Yang terpenting, meningkatnya kegairahan petani dalam produksi tanaman pangan akan berdampak pada tercapainya sasaran ketahanan pangan daerah dan nasional, serta dapat meningkatkan kontribusi sektor pertanian baik terhadap PDB daerah maupun PDB nasional.

\section{DAFTAR PUSTAKA}

Alam, Syamsul. (2015). Penulisan Artikel Ilmiah Untuk Publikasi Ilmiah Melalui Jurnal. Artikel E-Bulettin. Edisi April. Dalam http://www.lpmpsulsel.net/v2/attachments/353_Penulisan\%20 Artikel\%20Ilmiah\%20 Untuk\%20 Publikasi\%20Ilmiah\%20 Melalui\%20Jurnal.pdf. Diakses tanggal 29 Januari 2016.

Badan Pusat Statistik. (2014a). Laporan Bulanan Data Sosial Ekonomi Edisi 54, November 2014.Dalam http://www.bps.go.id. Diakses tanggal 13 Januari 2015.

. (2014b). Statistik Indonesia. 2014.Dalam http://www.bps.go.id/index.php/ publikasi/326. Diakses tanggal 13 Januari 2015.

Badan Perencanaan Pembangunan Nasional. (2014). Rencana Pembangunan Jangka Menengah Nasional 2015-2019. Dalam http://www.bappenas. go.id/. Diakses tanggal 12 Februari 2015

Boer, R. (2012). Asuransi Iklim Sebagai Jaminan Perlindungan Ketahanan Petani Terhadap Perubahan Iklim, Prosiding Widyakarya Nasional Pangan dan Gizi 10: Pemantapan Ketahanan Pangan dan Perbaikan Gizi Berbasis Kemandirian dan Kearifan Lokal, 20-21 November 2012.LIPI. Jakarta.

Food and Agriculture Organization. (2011). Agricultural Insurance in Asia and the Pacific Region. RAP Publication 2011/12. FAO. Bangkok.

Hazell, P., Pomareda, C., dan Alberto Valdes (1986). Crop Insurance for Agricultural Development: Issues and Experience. The Johns Hopkins University Press. London.

Iturrioz, R. (2009).Agricultural Insurance. Primer Series on Insurance Issue 12. The International Bank for Reconstruction and Development. The World Bank. Washington DC.

Nurmanaf, A.R., Sumaryanto, Wahyuni, S., Ariningsih, E., dan Yana Supriyatna. (2007). Analisis Kelayakan dan Perspektif Pengembangan Asuransi Pertanian Pada Usahatani Padi dan Sapi Potong. Makalah Seminar Hasil Penelitian T.A. 2007. Tersedia online http:// pse.litbang.pertanian.go.id. Diakses tanggal 26 Februari 2015. 
Pasaribu, S.M., Setiajie, I., Agustin, N.K., Lokollo, E.M., Tarigan, H., Hestina, J., dan Yana Supriyatna. (2010). Pengembangan Asuransi Usaha Tani Padi Untuk Menanggulangi Risiko Kerugian 75\% Akibat Banjir, Kekeringan dan Hama Penyakit: Usulan Penelitian. Tersedia online http://pse.litbang.pertanian.go.id/ Diakses tanggal 26 Februari 2015.

PT. Asuransi Jasa Indonesia. (2014). Asuransi Usaha Tani Padi (AUTP). Dalam Focus Group Discussion di Pusat Pengelolaan Risiko Fiskal, Badan Kebijakan Fiskal pada 21 Februari 2014.

PT. Pupuk Indonesia Holding Company. (2014). Pelaksanaan Asuransi Usaha Tani Padi 2012. Dalam Focus Group Discussion di Pusat Pengelolaan Risiko Fiskal, Badan Kebijakan Fiskal pada 17 Maret 2014.

Pusat Analisis Sosial Ekonomi dan Kebijakan Pertanian(PASEKP), Balitbang Pertanian, Kementan. (2009). Peluang Pengembangan Asuransi Pertanian di Indonesia. Warta Litbang Pertanian Vol 31 No 2 Tahun 2009. Hal 16-18.

Sugiyono. (2015). Metode Penelitian Kuantitatif Kualitatif dan R\&D. Cet. ke-22. Desember 2015. Alfabeta. Bandung.

Sumaryanto dan A.R. Nurmanaf. (2007). Simpul-Simpul Strategis Pengembangan Asuransi Pertanian Untuk Usaha Tani Padi di Indonesia. Forum Penelitian Agro Ekonomi Vol 25 No. 2 Desember 2007. Hal. 89-103.

Supartoyo, Y.H. dan Kasmiati. (t.t). Asuransi Pertanian Sebagai Alternatif Mengatasi Risiko Usaha Tani Menuju Pertanian Berkelanjutan: Tinjauan Konseptual. Tersedia online https://www.academia.edu. Diakses tanggal 26 Februari 2015.

Warner, K., Ranger, N., Surminski, S., Arnold, M., Linnnerooth-Bayer, J., Michel-Kerjan, E., Kovacs, P., dan Celine Herweijer. (2009). Adaption to Climate Change: Linking Disaster Risk Reduction and Insurance. United Nations International Strategy for Disaster Reduction (UNISDR). Geneva, Switzerland.

World Bank. (2010). Agricultural Insurance in Latin America, Developing the Market.Report No.61963-LAC. Desember 2010. World Bank Insurance for the Poor Program. Washington DC. 
